\title{
Comments upon the sources of the Church Slavonic-Ruthenian Lexicon by Pamvo Berynda
}

\author{
Alexander Levichkin * \\ Institute of Linguistic Studies, Russian Academy of Sciences, Tuchkov pereülok 9, 199053 Saint Petersburg, Russia
}

\section{Article info}

History:

Received September 21, 2021

Accepted September 30, 2021

Published December 12, 2021

Key words:

historical lexicology

old documents

philology

text editing

\begin{abstract}
The article examines some of the sources of Pamvo Berynda's Church SlavonicRuthenian lexicon. Identifying the sources of the dictionary and all the hidden quotes is an important task for the correct presentation of the content of this lexicographical monument. The quoted content presented in the Lexicon is divided into two groups: material that did not indicate the source (an example is the Interpretation of words difficult to understand) and materials that indicated the source. For the second case, a non-exhaustive list of such examples is provided. Such quotations show that, for his Lexicon, Berynda mainly used works in the printing of which he himself participated. These are the Homilies on the Acts of the Apostles and the Homilies on the 14 Epistles of the Holy Apostle Paul, both belonging to John Chrysostom, along with the Didactic Gospel. The use of dictionary entries in the Interpretation of words difficult to understand, a lexicon based on the vocabulary from the Ladder of Divine Ascent, and from Interpretation of words in alphabetical order by Maximus the Greek confirms Berynda's interest, indicated by other researchers as well, for the previous lexicographic tradition.
\end{abstract}

\section{Introduction}

The critical edition of the Church Slavonic-Ruthenian lexicon by Pamvo Berynda (in what follows, Lex$i c o n$ ) in the printed and electronic format still remains a relevant task. For a detailed edition it is necessary, first and foremost, to study the principles of the Lexicon's composition, the selection of lexis, the structure of dictionary entries, the system of marks, its sources and other characteristics of the dictionary. The present article is aimed at looking more closely at some sources of the Lexicon compiled by Berynda.

Pamvo Berynda himself shortly mentions the sources of his Lexicon in the introduction to this dictionary (here and in what follows we use the materials of the 1627 edition of Berynda's Lexicon, the copy of the Russian National Library, II.5.21a) and in another article at the end of the Lexicon-Чита́телю $\mathrm{C}_{\Pi}{ }^{\widehat{c}}$ Hï出 (the columns 476-477, vôs-vö3), where he indicates only several sources: the Lexis by Lavrenty Zizany (Vilno, 1596), the Antwerp Bible, Maximus the Greek, Manuel Holobolos, the Homelies on the Acts of the Apostles and the Homelies on the Epistles of the Apostles. This aspect was also remarked by other scholars studying the Lexicon (see Arkhangel'skiı̌, 1902; Janów, 1951; Nimciuk, 1961). Among the recent studies we would like to underline the article by Kalugin (2014), who analyses the dictionary by Maximus the Greek intitled Interpretation of words in alphabetical order as one of the sources of the Lexicon.

\section{Sources which are not mentioned in the lexicon entries}

As highlighted by the previous research, Berynda does not mention the source of his material in dictionary entries. An example in this respect is Interpretation of the words difficult to understand, created on the basis

^Email address: alevi66@gmail.com. 
Alexander Levichkin

of the materials from the Ladder of Divine Ascent by John Climacus (published and commented upon in Kovtun, 1963, p. 216-268, 421-431). A part of these entries makes references to the Ladder of Divine Ascent, for example, see the following entries (here and in what follows, we will indicate the number of the column and the page from the edition Nimciuk, 1961 in angle brackets:

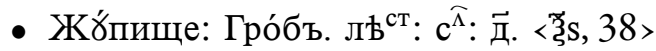

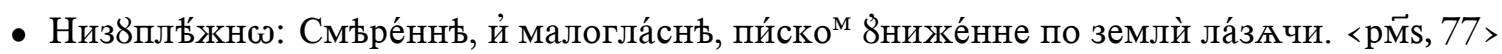

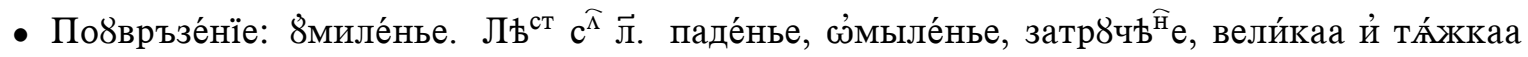
ต’спа́лость. <рӧв, 90>

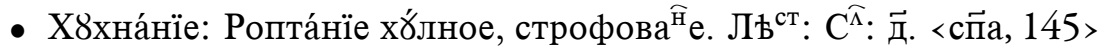

The other part of the entries, which sometimes extend the definition, have no indication of their source; for example, see the following entries:

- Бо́хма: Ве́сма, зго́ла, напра́сно, <ёi, 12> (cf. Kovtun, 1963, p. 429)

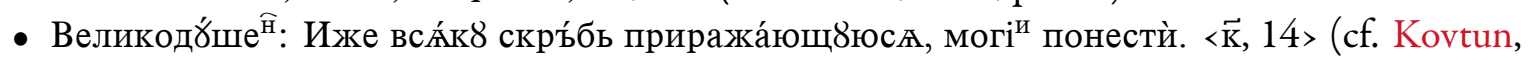
1963, p. 431)

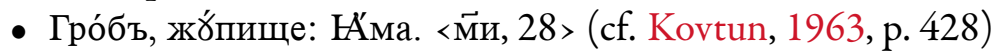

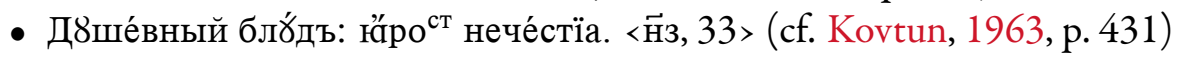

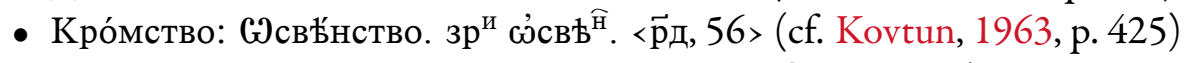

- Сме́рчъ: Піа́вица, о̋блакъ дожде́вный, ф8ртбина. <ск̈s> (cf. Kovtun, 1963, p. 424)

- Ръсноти́вїе: Истинню. <св̈і, 110> (cf. Kovtun, 1963, p. 429)

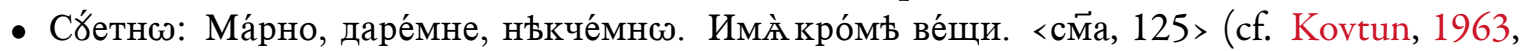
p. 430)

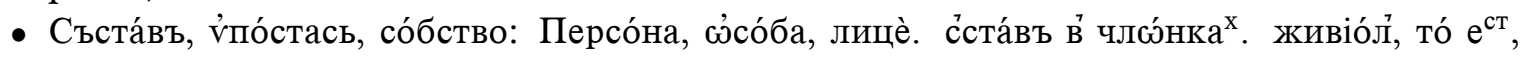

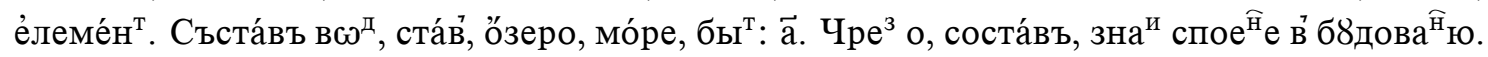
зрѝ Соста ${ }^{\widehat{B}}$. <см $\Theta$, 129> (cf. Kovtun, 1963, p. 425).

Another possible source used by Berynda is writings on grammar. We can assume that he used the ma-

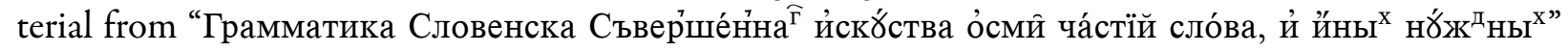
by Lavrenty Zizany (Vilna, 1596) and “Грамматіки Славе́нскиґ пра́вилное Cи́нтагма" by Meletius Smotrytsky (Vievis, 1619) (see these works published in Kuzminova, 2000) or Adelfotes ('A $\delta \varepsilon \lambda \phi o ́ \tau \eta s$. Грамматика доброглаголиваго еллинословенскаго не́зы́ка. Соверше́ннаго и́ск8ства о̉смѝ часте́й сло́ва. Ко наказа́нию многоимени́том8 Ро ${ }^{\widehat{c}}$ сійском8 ро́дб) (Lviv, 1591). The indications to "grammar" or "orthography" are rare; see, for example:

- Сло́гъ: Скла́дъ. Естъ тыж в

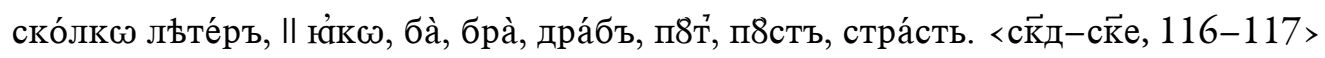

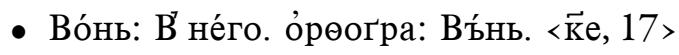

The indications to the use of grammars appear in grammar notes:

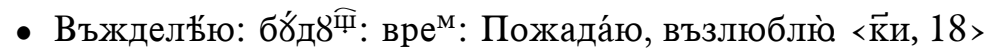

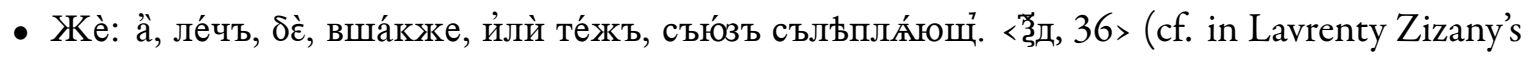
Grammar: Кї^ с8тъ съльплА́ющіА; й, оўбо, жѐ. (leaf 84), Kuzminova, 2000, p. 104)

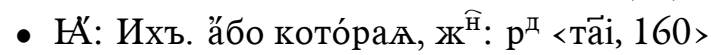

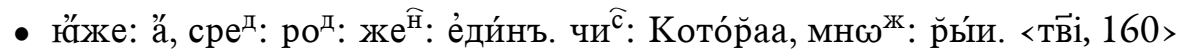

In what follows, we will turn to the sources mentioned in dictionary entries. Here, like in many other cases, Berynda uses an abbreviated form of the notation of sources, which might create difficulties in their 
identification. Sometimes the way of abbreviating, as well as the organisation of the abbreviations can alter. In the case of printed sources, the author mentions the "leaf" of the edition (the "leaf" can refer to either page or column), and the quotes from the source sometimes follow its title.

The easiest to differentiate are printed editions with the reference to a leaf. Thus, we can indicate the following editions: John Chrysostom, Homilies on the Acts of the Apostles (Kiev, 1624), e.g.:

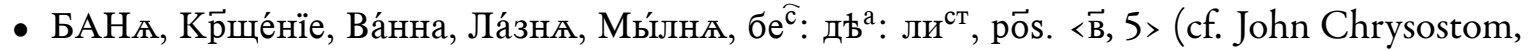

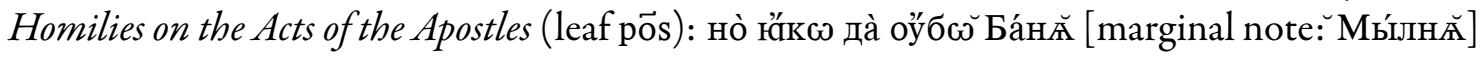
ббидетъ.)

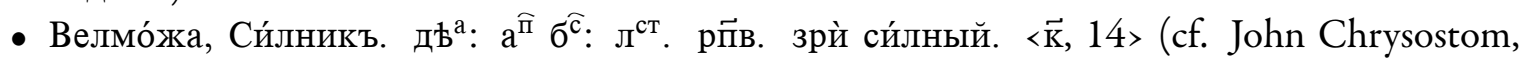

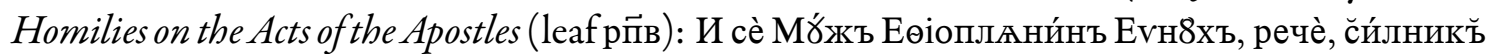
[marginal: в̆елмо́жӑ] Канда́кии Цари́ци Еөіо́пскїґ.)

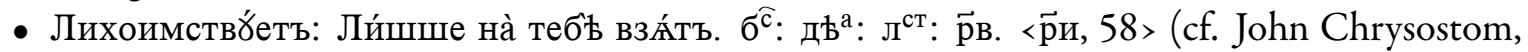

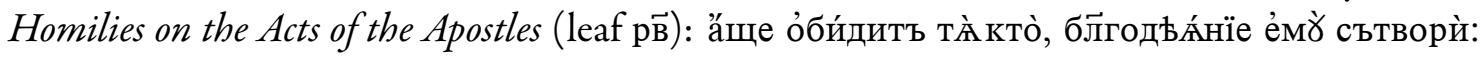
äще лихоимствйетъ, бл̈гословѝ.)

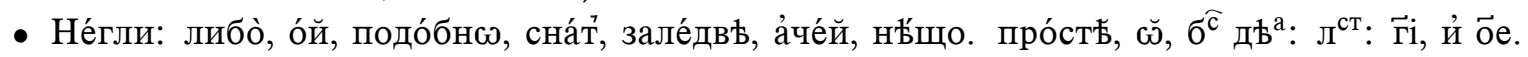

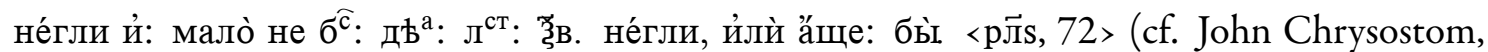

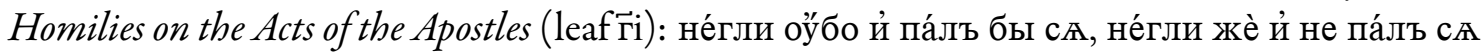

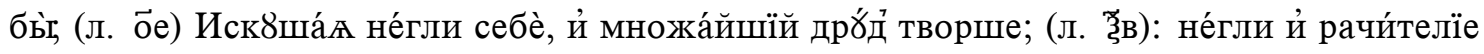
бы́сте пвсть́нниїи.)

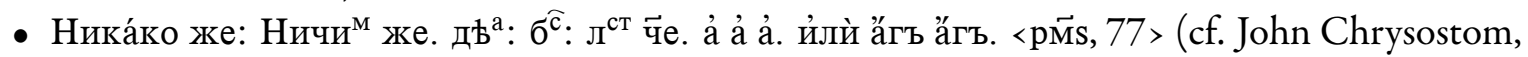

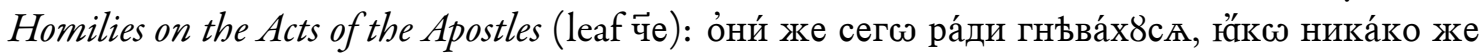

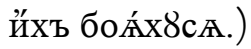

Another printed edition which was often used by Berynda is the Homilies on the 14 Epistles of Saint Paul the Apostle by John Chrysostom (Kiev, 1623), e.g.:

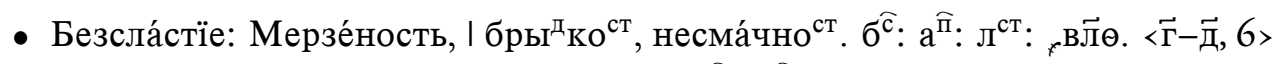

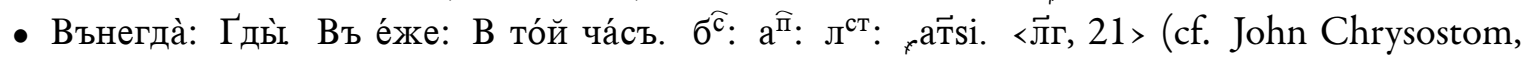
Homilies on the Epistles (column ${ }_{r}$ aTึsi): й мздá же внегда̀ твори́ти до́бръ)

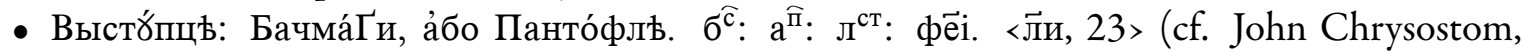
Homilies on the Epistles (column ${ }_{f}$ феі): И па́ки ёст нъ́кто, высо́къ мถ́рою телесѐ. йнъ же кра́токъ сь́й, възе́мъ Высотช́пцъ, высоча́шый быва́ет.)

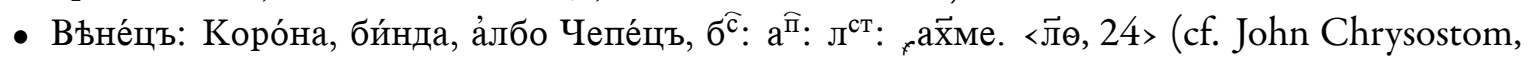

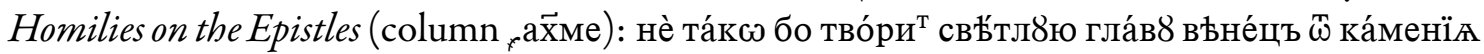
сло́женый сәблежа́щый)

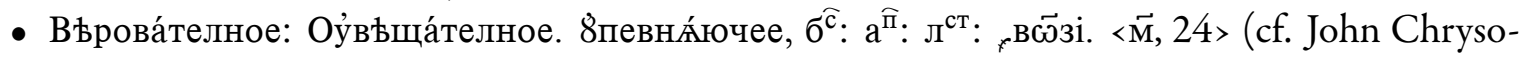

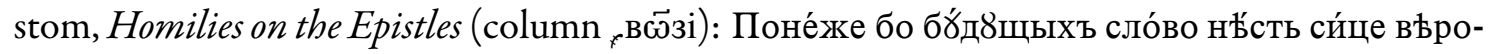
ва́телное)

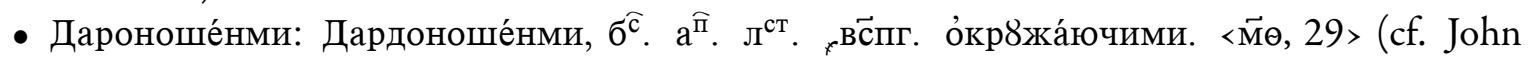

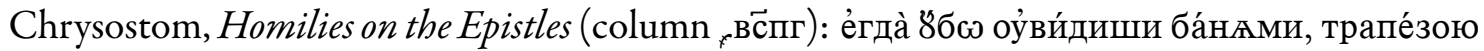
многоцьнною, и́лѝ дароноше́нми йными наслажда́ющас® о̋нсиц8)

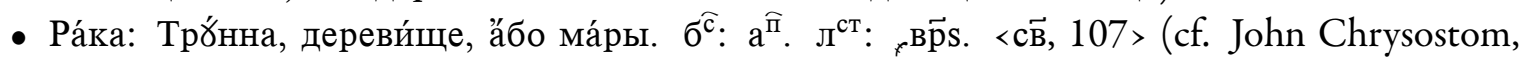
Homilies on the Epistles (column ${ }_{f}$ врिs.): семй погребе́нїю нѝ ри́зъ, нѝ ра́ки, нй йного чесо́го ఉ тако́вы ${ }^{\mathrm{x}}$ потре́ба).

Among the sources we can identify references which contain only a number indicating the column from the printed book. Such cases are numerous; they also refer to the edition mentioned above:

- Загражда́ю: За8жа́ю, встог. <о̆а, 40> (cf. John Chrysostom, Homilies on the Epistles (column

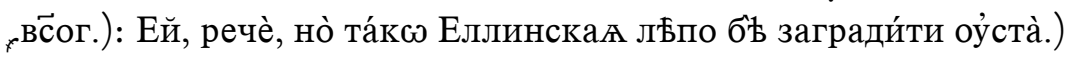




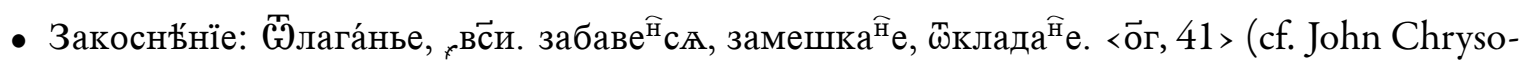

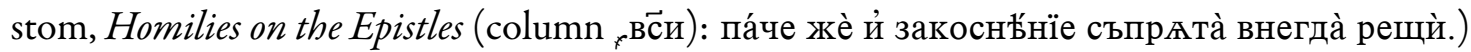

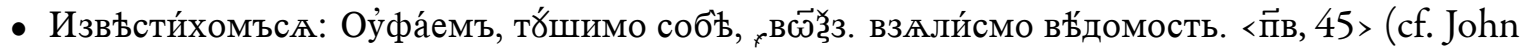

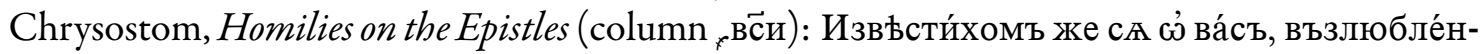
нііи).

There are also some references to the Didactic Gospel (Krylos, the typography by the Church of the Dormition of the Mother of God, 1606), e.g.:

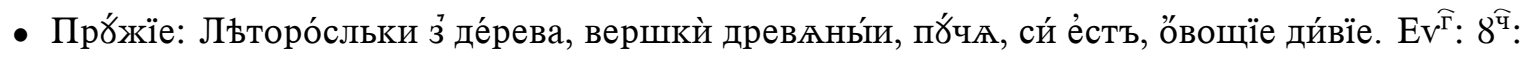

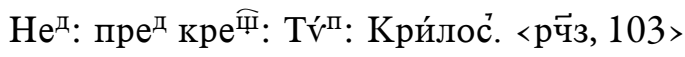

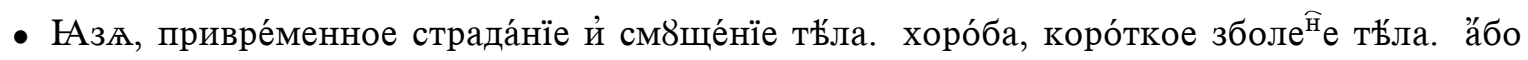

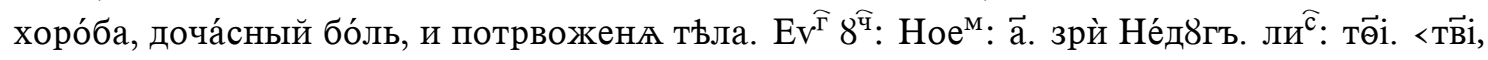
160>

A reference with the note "leaf" sends us to the printed edition of the Akathist:

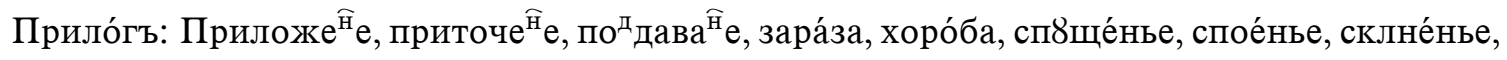
оўдаре́нье, натертьѐ, оу́та́рчка, ча́та, при́кладъ, прида́ток’, Тира́нское оу́тисне́нье. намъ̆т-

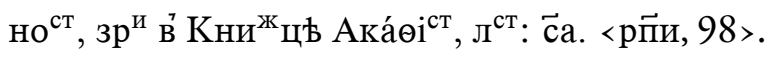

References which do not mention the "leaf" send us not to printed volumes, but to manuscripts. Among these there are the following references:

Abba Dorotheus:

- Б8бре́ги: Нь́рки. Доро ${ }^{\widehat{\theta}}: \Gamma^{\widehat{\Lambda}}: \vec{\Gamma}$. <ёi, 12>

- Стрйчецъ: стр8чо́къ. ки́стка, пе́ндзликъ. До

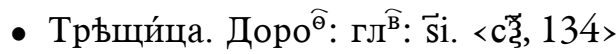

Andrew of Crete:

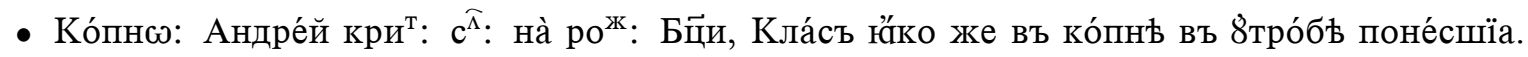
Полбкопо ${ }^{\widehat{\mathrm{K}}} .<\overrightarrow{\mathrm{p}}, 54>$

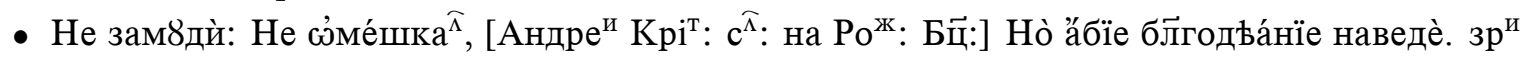
м8дне́нїе. <рлии, 73>

Saint Basil the Great:

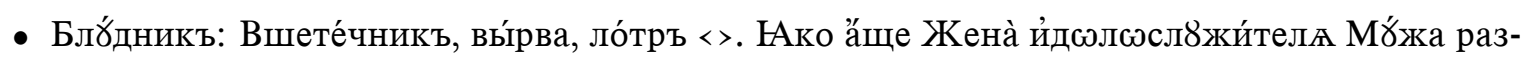

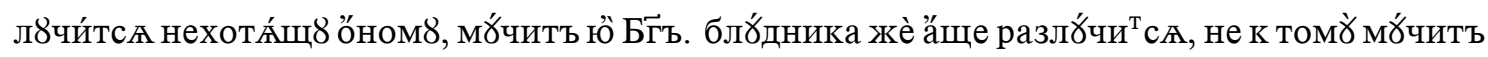

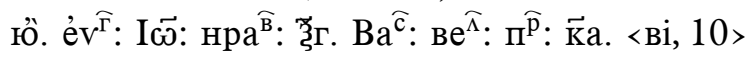

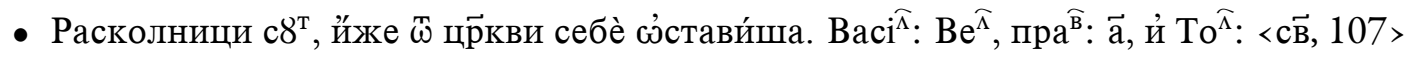

Germanus of Constantinople (On the Divine Liturgy):

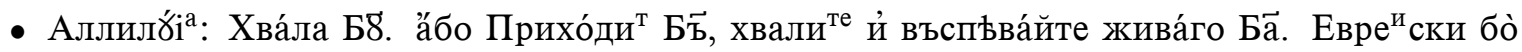

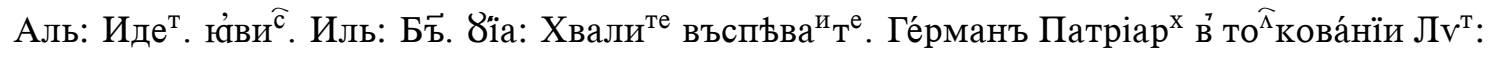

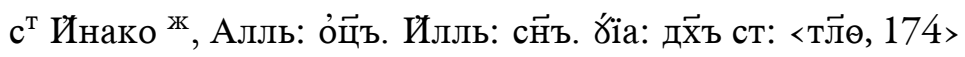

Gregory the Theologian (16 homilies of Gregory the Theologian with comments by Nicetas of Heraclea):

- Безче́стї, досажде́нїе. Зелжи́вость, срамо́та. Безче́стї е ${ }^{\text {ст }}$, слове́сн8 молча́ти, ๗’ йх же

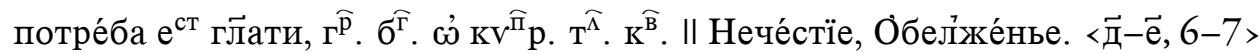




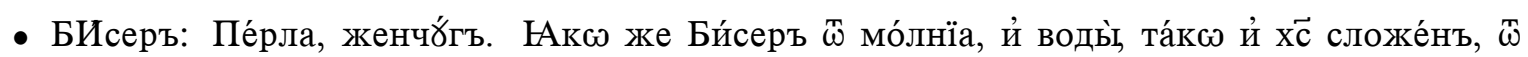

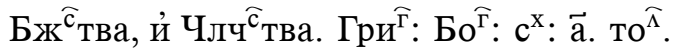

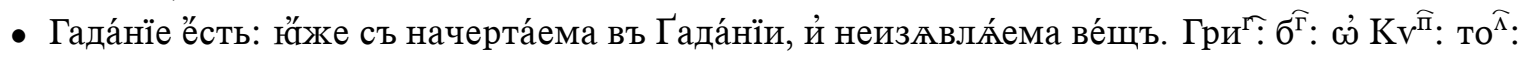

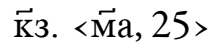

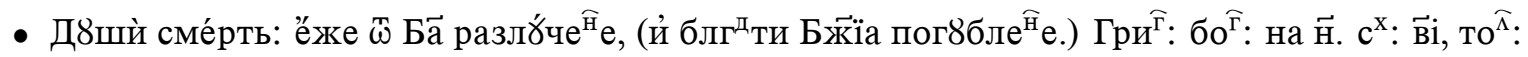
$\langle\overrightarrow{\mathrm{H}} 3,33\rangle$

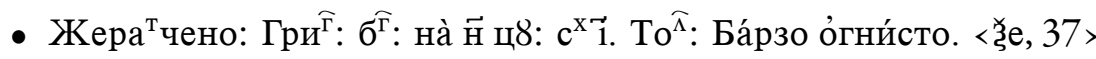

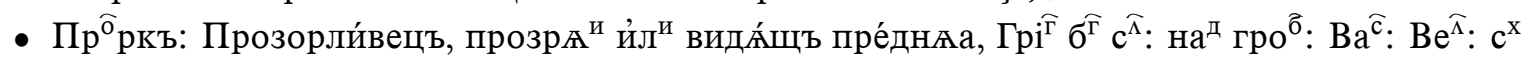
кии. <рче, 102>

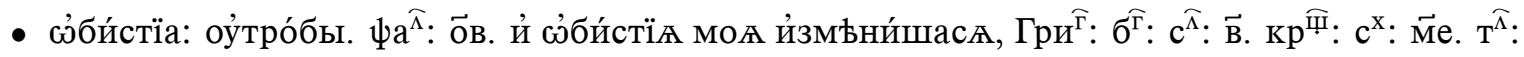
$<$ cחs, 147>

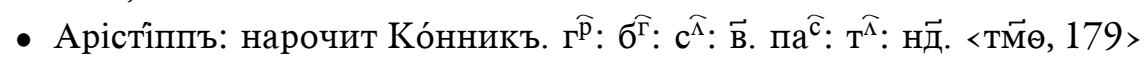

Ephrem the Syrian:

- Жи́то: Имъ̆нїе. е̇фре ${ }^{\mathrm{M}}: \mathrm{c}^{\widehat{\Lambda}}: \vec{\Gamma} .\left\langle\mathfrak{\zeta}_{3}, 38>\right.$

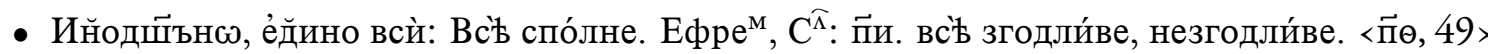

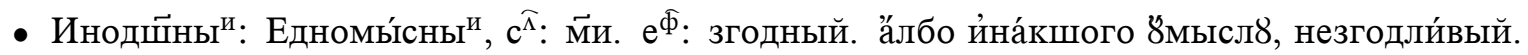
$\langle\vec{\Pi} \Theta>$

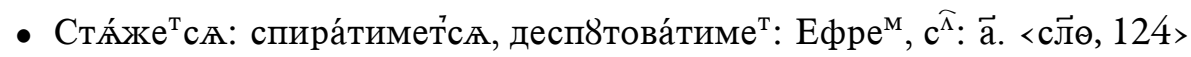

John of Damascus (An Exact Exposition of the Orthodox Faith; possibly, some other works as well):

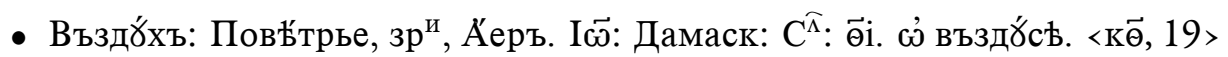

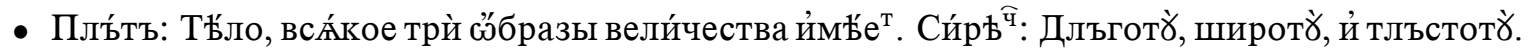
I $\vec{\omega}:$ Да $^{\mathrm{M}}: \mathrm{KH}^{\widehat{\Gamma}}: \overrightarrow{\mathrm{B}} \cdot \Gamma^{\widehat{\Lambda}} \cdot \vec{\Gamma} \cdot\left\langle\mathrm{pH}^{3}\right\rangle$

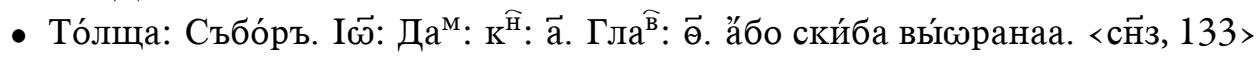

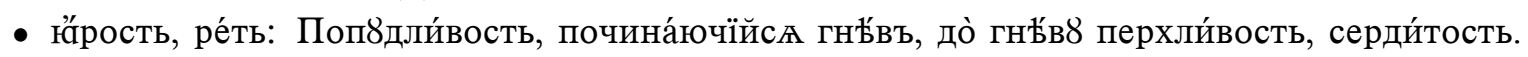

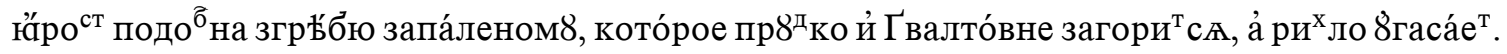

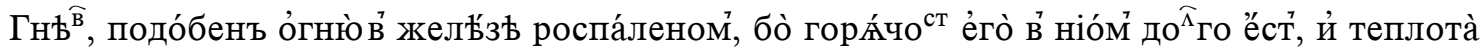

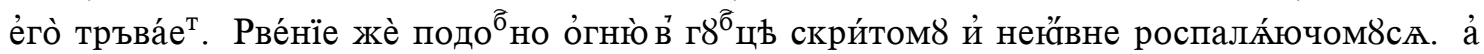
до чого̀ при ${ }^{\mathrm{T}}$ кне́тс离 всѐ па́литъ, й на ${ }^{\text {म }}$ о́бо́хъ го́ршее: до́лжей гори́тъ нега́сн8чи. та ${ }^{\widehat{K}}$ и́

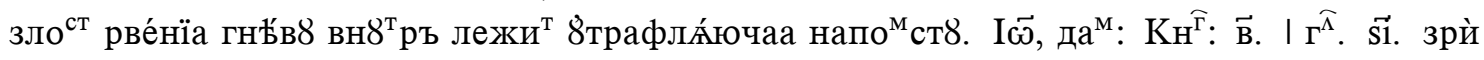

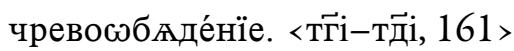

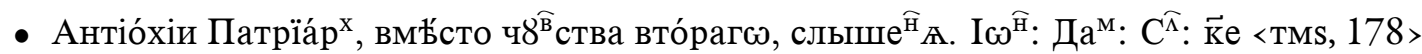

John the Exarch (Introduction to the Gospel interpretation; at present there are doubts as to the attribution to this author):

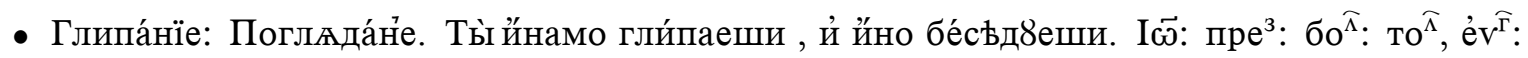
про $\mathrm{\Lambda}^{\widehat{\Lambda}}:\langle\overrightarrow{\mathrm{MB}}, 25>$

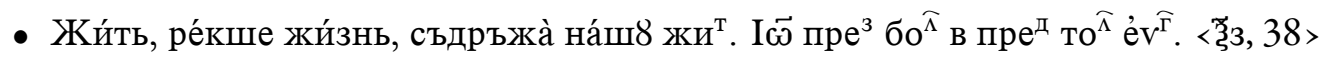

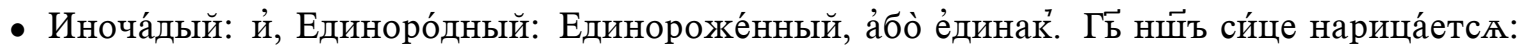

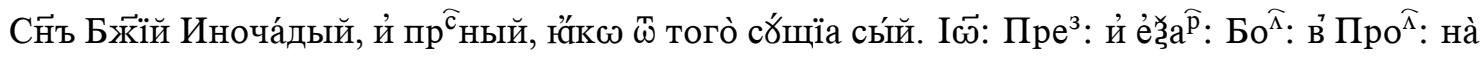
$\mathrm{To}^{\widehat{\Lambda}}: \mathrm{Ev}^{\widehat{\Gamma}}:\langle\vec{\Pi} \Theta, 49>$

John Chrysostom (see Margarit below):

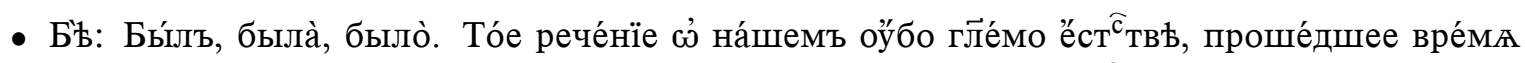

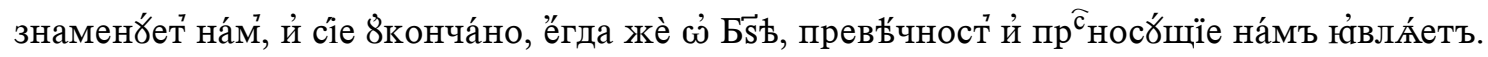
Зла ${ }^{\mathrm{T}}$ оу $^{\text {ст }}: \mathrm{I \omega}:$ бе $: \vec{\Gamma} .\langle\overrightarrow{3} \mathrm{i}, 13>$ 
Alexander Levichkin

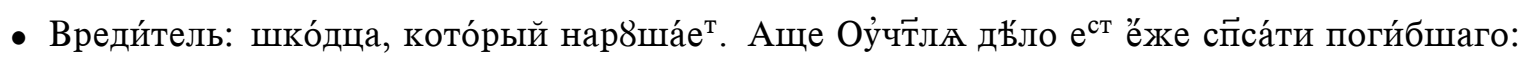

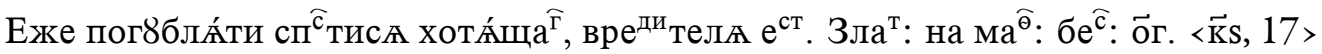

- До́ндеже: Ажъ по́ки: й ты́жъ на́вظки, а̋жбымъ: ăлбо по́ки а̋жъ, а̉бò ăжъ. Обы́чай Писа́нїю

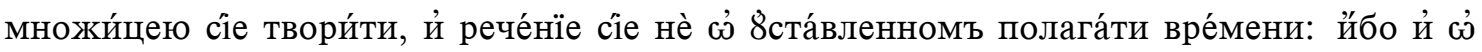

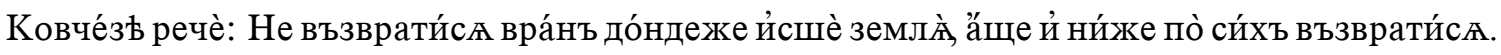
Зла ${ }^{\mathrm{T}}$ оу $^{\mathrm{cT}}:$ ма $^{\widehat{\Theta}}:$ бе $\mathrm{e}^{\widehat{\mathrm{c}}}: \overrightarrow{\mathrm{e}} .<\overrightarrow{\mathrm{H}}$ д, 31>

Cyril of Alexandria:

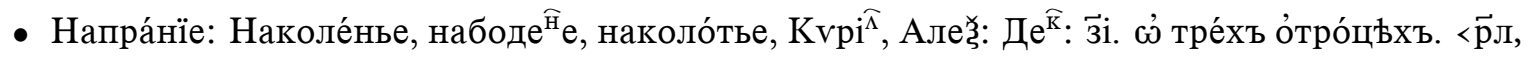
69>

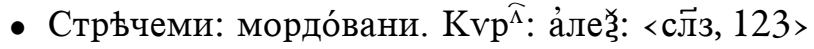

Cyril of Jerusalem:

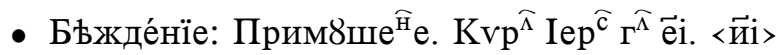

- Ви́стнъе: Оўпріймъ. Kvpi ${ }^{\widehat{\Lambda}} \operatorname{Iep}^{\widehat{c}}: \Gamma^{\widehat{\Lambda}}:$ ёi. $\langle\overrightarrow{\mathrm{K}}$ в, 15>

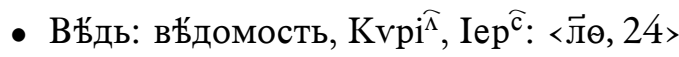

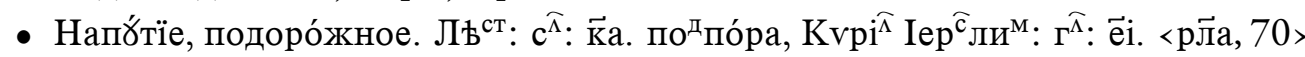

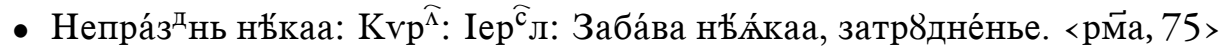

- Нива́ръ: СелАни ${ }^{\overparen{H}}$. Кvрі ${ }^{\widehat{\Lambda}} \operatorname{Iep}^{\widehat{\widehat{c}}} л и^{\mathrm{M}}:\langle\mathrm{p} \overrightarrow{\mathrm{M}} \mathrm{s}, 77>$

- Подо́бство: Подобе ${ }^{\widehat{\mathrm{H}}}$ ство. Кvpi ${ }^{\widehat{ }} \operatorname{Iep}^{\widehat{c}}:\left\langle\mathrm{p}^{\widehat{3}}\right.$ в, 85>

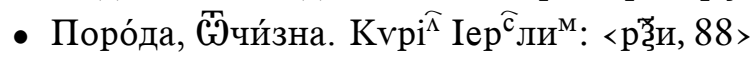

- Прикла́да: Kvpi ${ }^{\widehat{\Lambda}} \operatorname{Iep}^{\widehat{c}}$ : прировна ${ }^{\widehat{\mathrm{H}}}$, прировнова ${ }^{\widehat{\mathrm{H}}} \mathrm{e}$. Земл六 толи́к8 йма ${ }^{\mathrm{T}}$ нб̋си прикла́д8, ёли́ка сре́да коле́снаа къ всемб̈ о’крб̈жїю. <рп्̈з

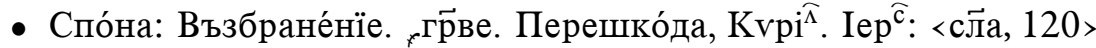

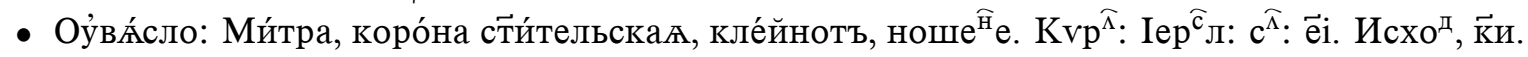
<с Зु̆д, 136>

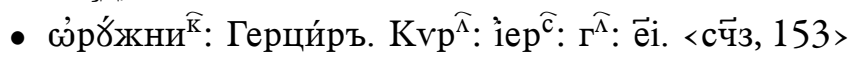

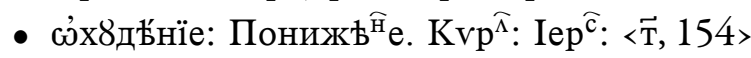

Nikephoros Kallistos (possibly, it refers to the Didactic Gospel):

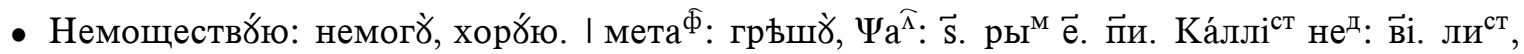

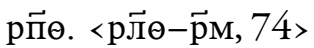

Cornucopia (possibly, it refers to the edition of the book by Niccolò Perotti Cornucopie / Cornu Copic):

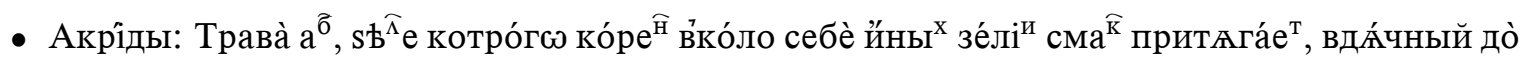

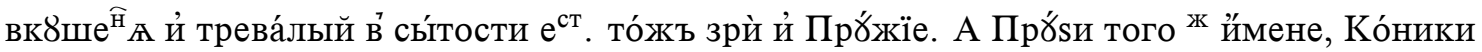

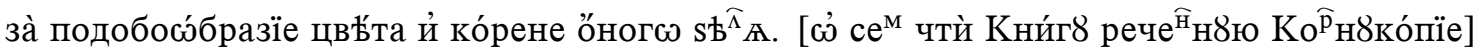

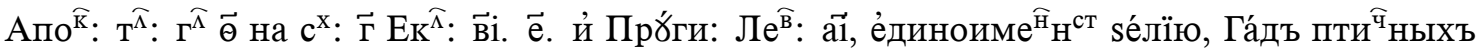
разли́чна ро́да. <тл̈з, 173>

The Ladder of Divine Ascent by John Climacus:

- Въсплища́ю: Засмйч8ю. ль $\mathrm{b}^{\widehat{c}}: \mathrm{c}^{\widehat{\Lambda}} . \vec{\Gamma} .<\widetilde{\pi s}, 22>$

- Гребло̀ Корми́лное: Сты́ръ, ко́рма. Лъ ${ }^{\text {ст }: ~} \mathrm{C}^{\widehat{\Lambda}}: ~ \breve{3}$ i. $<\widehat{\mathrm{M}} 3,28>$

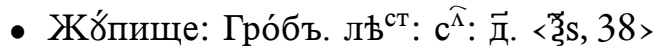

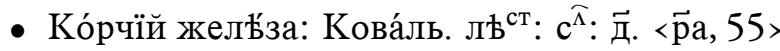

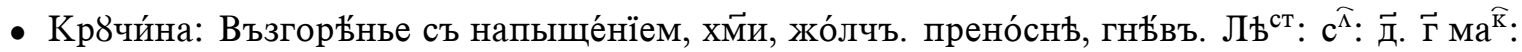
е. $\langle\overrightarrow{\mathrm{p}}$ д, 56> 


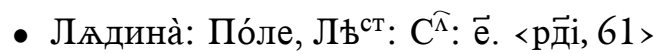

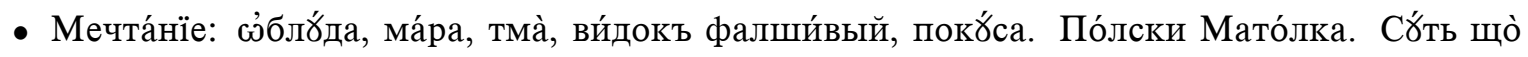
лю́демъ слйжатъ, в Ла́пїи, в̈ шве́цїи, покйсы. мечта́нье: помышле́нье, а̋лбо ме́че ${ }^{\mathrm{T}}$, ацккд:

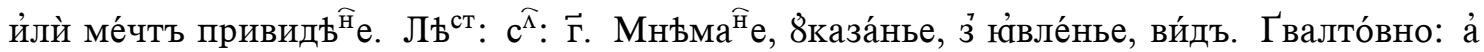

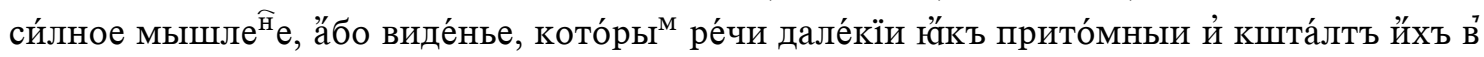

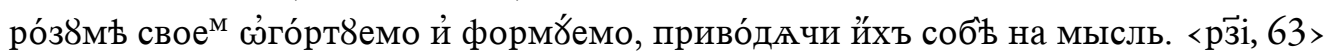

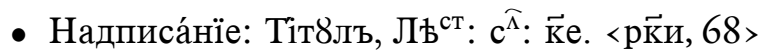

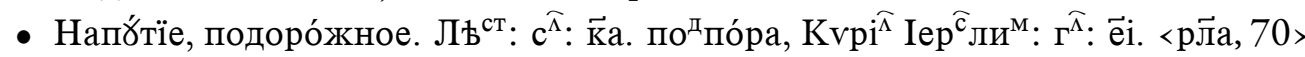

- Непоше́ствїе: Непор8ше ${ }^{\widehat{H}}$ e. $\boldsymbol{\jmath}^{\mathrm{cT}} \mathrm{c}^{\widehat{\Lambda}} \vec{\Gamma}$. $\langle$ рмМа, 75>

- Нова́къ: Новицїа́т, Лљ ${ }^{\text {cт }} \mathrm{c}^{\widehat{\Lambda}}: \overrightarrow{\text { д. }}<\mathrm{p} \overrightarrow{\mathrm{M}} 3,78>$

- Писа́ло: Спо́co ${ }^{\widehat{B}}$ писа́нА. ль ${ }^{\mathrm{cT}} \mathrm{c}^{\widehat{\Lambda}} \overline{3 i}$. $\langle$ рнд, $81>$

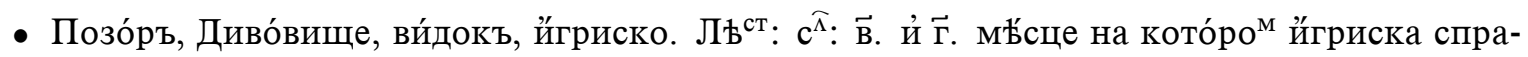

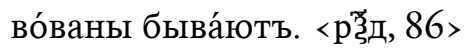

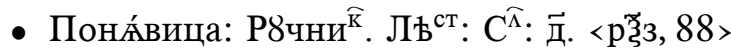

- По́ртище: С8кно̀. Лъ ${ }^{\text {ст }}: \mathrm{C}^{\widehat{\Lambda}}: \overrightarrow{3}$ i. $<\mathrm{p}^{\mathfrak{x}} \Theta$, 89>

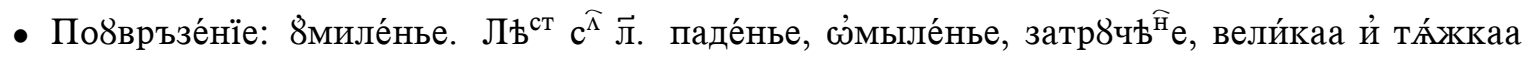
сэспа́лость. <рӧв, 90>

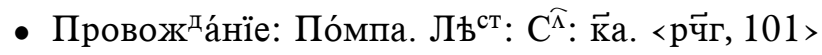

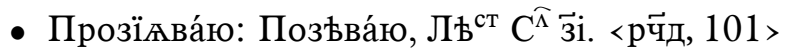

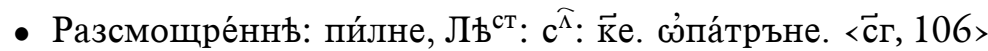

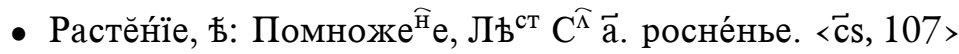

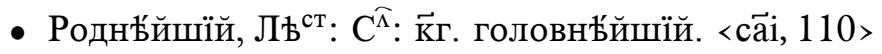

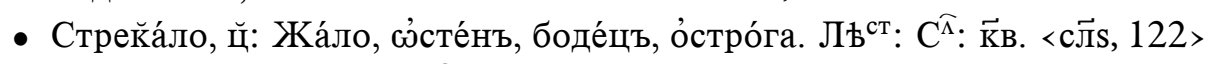

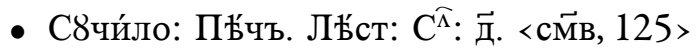

- Съпротивле́нїе: Противле́нье. Лъ ${ }^{\text {ст }}: \mathrm{C}^{\widehat{\Lambda}}: \overrightarrow{\mathrm{Ke}}$. $<$ смй, 128>

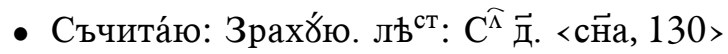

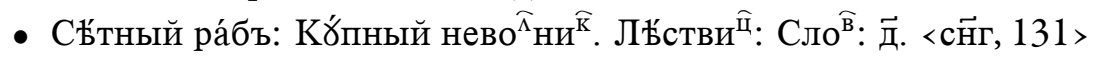

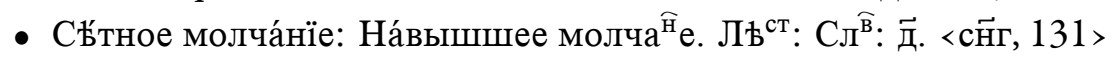

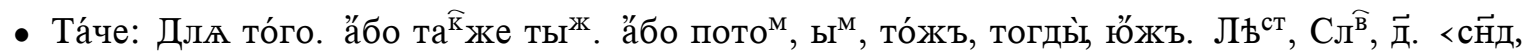
131>

- Тризнополо́жникъ, Лъ ${ }^{\text {cr. }}: \mathrm{C}^{\widehat{\Lambda}}: \overrightarrow{\mathrm{a}} .<\mathrm{cH} \Theta, 134>$

Maximus the Greek:

- Ва́снь: хра́пъ, мнЊ̋́нье. Сна́ть, ба́чъ, ве́й, нема́ль, не́гли, II нъ̌что. Сіи посло́вицъ, ёди́нъ

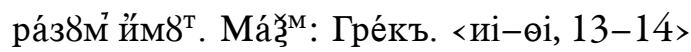

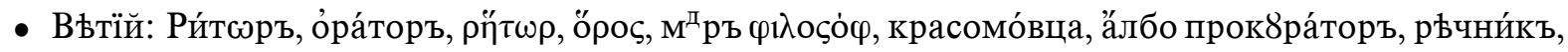
хитросло́вецъ. Маъ̧ॅ: $\langle$ м, 24>

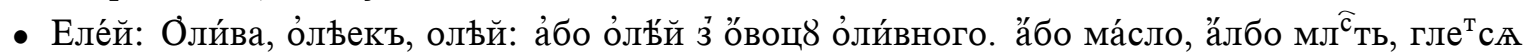
по̀ на́шем8 сло ${ }^{\widehat{B}}$. Мá ${ }^{\mathrm{M}}:$ на̀ $\Psi \mathrm{a}^{\widehat{\Lambda}}: \overrightarrow{\mathrm{p}} \mathrm{M} .\left\langle{ }_{\mathrm{B}} \mathrm{B}, 35>\right.$

- Жела́нїе: ПрагнЊ̋́нье, жаданье, пожадли́вость, хйть, хти́во ${ }^{\text {ст }}$, и́лѝ по́хо ${ }^{\mathrm{T}}$, Крайнъ̆йше про́-

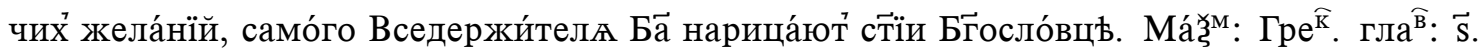
<३зд, 36>

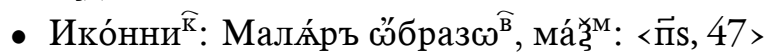

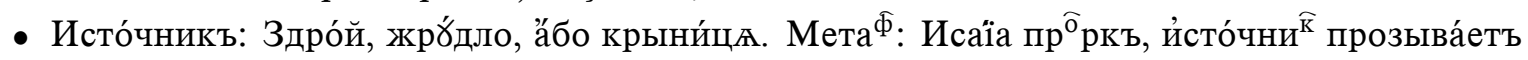

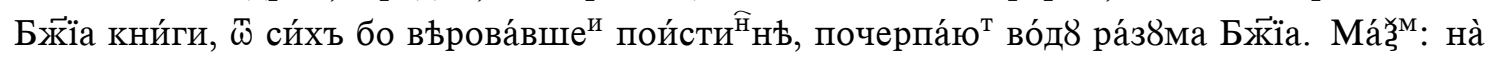
йcáïю. 〈

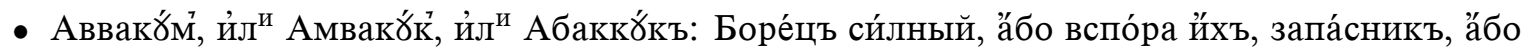

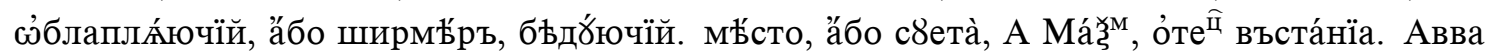

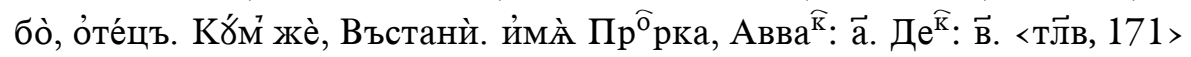


Margarit (John Chrysostom, the Book called Margarit):

- Сб́ета: Ма́рность, нъкче́мно ${ }^{\text {ст }}$, поро́жность, даре́мность. мета ${ }^{\Phi}:$ По́длость, де́шевость,

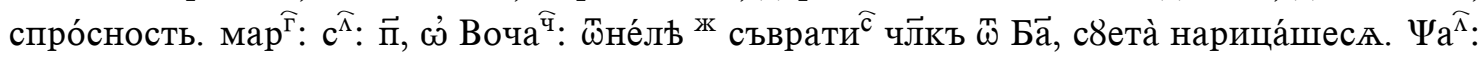

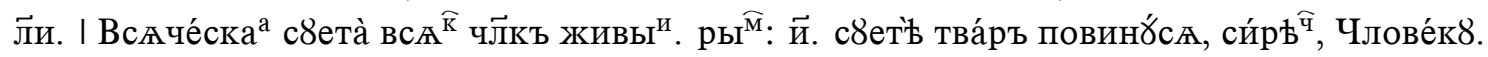
$<\overrightarrow{\mathrm{C} M}, 124>$

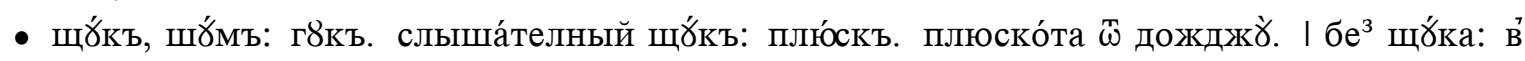

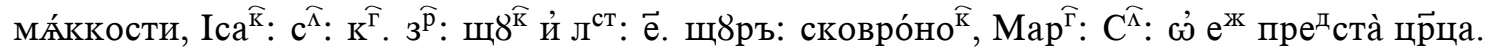
$\langle\overrightarrow{\mathrm{T}} \Theta-\overrightarrow{\mathrm{T}} \mathrm{i}, 159\rangle$

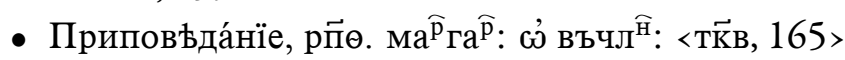

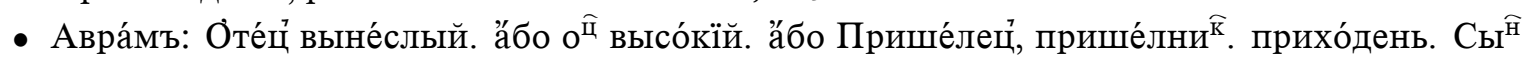

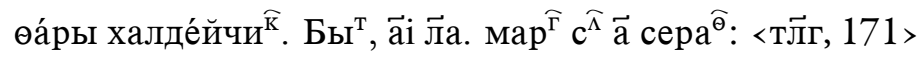

Nikon of the Black Mountain:

- Водова́жда: Капа ${ }^{\widehat{ }}$, Смо́к што̀ во́д8 вытАга́ет̉ в̉ горё, й те́жъ ж8раве́ль: Напра́ви Водова́жд8 напаќ́ти но́щїю село̀. $\mathrm{Hi}^{\widehat{\mathrm{K}}}: \mathrm{c}^{\widehat{\Lambda}}: \overrightarrow{3} \mathrm{i} .<\overrightarrow{\mathrm{K}} д, 16>$

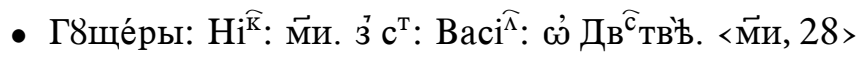

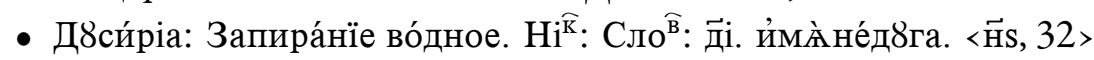

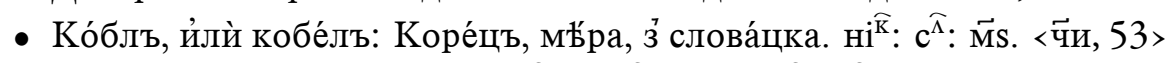

- Корва́нъ: Да́ръ, а̋бо о’фърова ${ }^{\widehat{\mathrm{H}}} \mathrm{e} \cdot \mathrm{мa}^{\widehat{\mathrm{p}}}: \overrightarrow{3} \cdot \overrightarrow{\mathrm{a}} \cdot \mathrm{Hi}^{\widehat{\mathrm{K}}}: \mathrm{C}^{\widehat{\Lambda}}: \overrightarrow{\mathrm{M}} \Theta .\langle\overrightarrow{\mathrm{p}}, 54>$

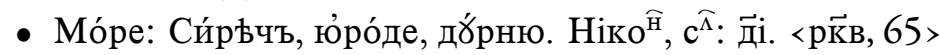

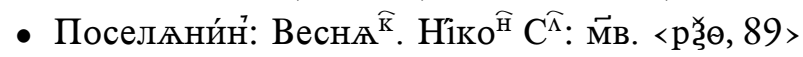

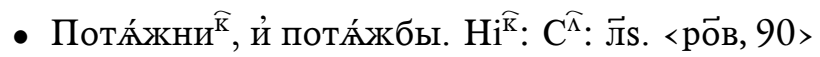

- Ра́тай: Ніко ${ }^{\widehat{H}}, \mathrm{C}^{\widehat{\Lambda}}: \overrightarrow{\mathrm{H}} 3$. ора́чъ. $\langle\overrightarrow{\mathrm{cs}}, 107>$

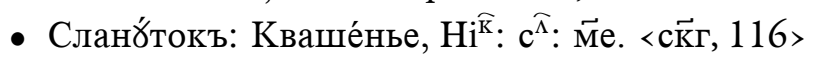

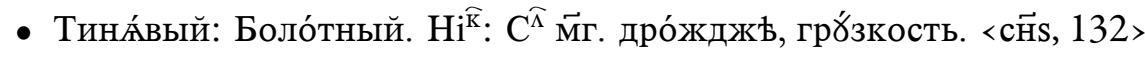

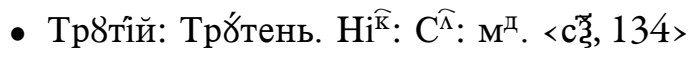

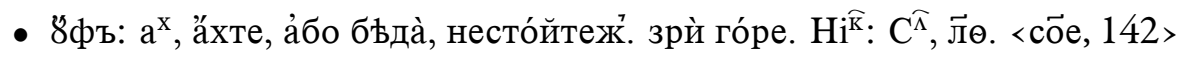

- Хльбница: Пека́рнА․ $\mathrm{Hi}^{\widehat{\mathrm{K}}}: \mathrm{C}^{\widehat{\Lambda}}: \overrightarrow{3}$ i. $<$ со̆и, 143>

- Кैзнаръ: $\mathrm{Hi}^{\widehat{\mathrm{K}}}: \mathrm{C}^{\widehat{\Lambda}}: \overrightarrow{\mathrm{M}} \mathrm{e} .<\mathrm{TB} \mathrm{B}, 160>$

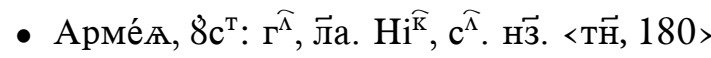

\section{Skete Paterikon:}

- Дช́хъ пүөо́нскїй, Па ${ }^{\mathrm{T}}:$ ск $^{\mathrm{T}}: \mathrm{c}^{\widehat{\Lambda}}:\langle\overrightarrow{\mathrm{H}} 3>$

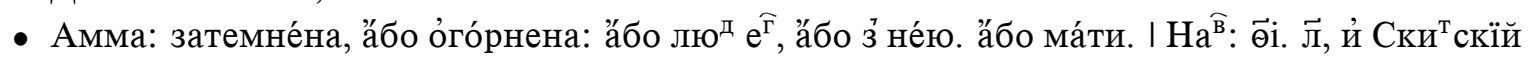
патерїк $\langle$ т $\overrightarrow{\mathrm{M}}-\mathrm{T} \overrightarrow{\mathrm{M}} \mathrm{a}, 175>$

Paterikon of the miracle workers from Solovky (possibly, the Life of Zosimas and Savvatiy from Solovky):

- КлАпи́на: ВсÁкое дре́во нагне́ное, Моско́вски нарица́етсґ, Патери ${ }^{\widehat{K}}$ Солове́цки ${ }^{\mathrm{x}}$ ч8дот-

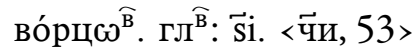

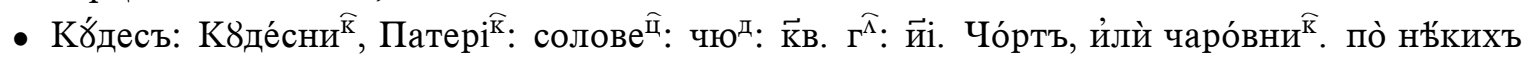

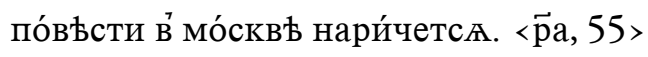

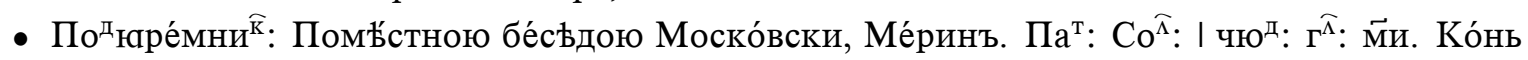
про́сты ${ }^{\text {. }}$ Ло́ша ${ }^{\text {म }}$, са́мка, про́стаa клА́ча. 〈р艿, 85>

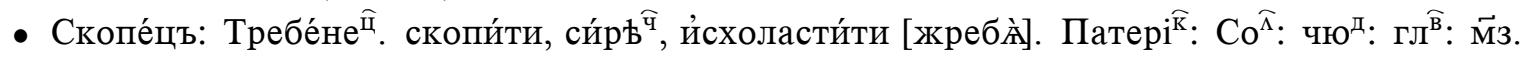
<ска а, 115>

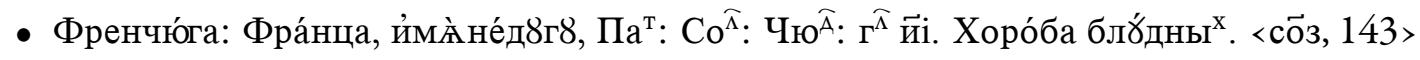


Consuetudinary (possibly, the monastery consuetudinary by Joseph Volotsky in the Extended edition included in the Great Menaion Reader, see Kalugin, 2014, p. 199):

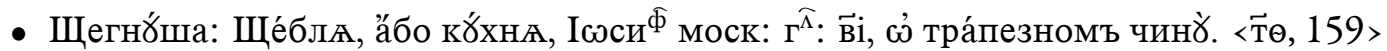

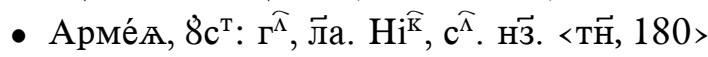

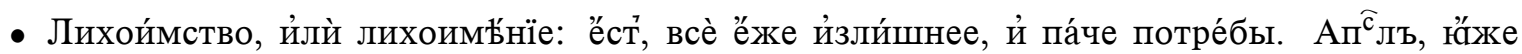

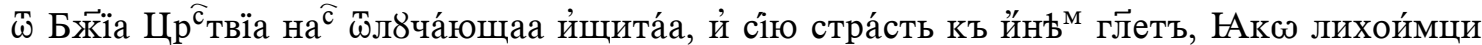

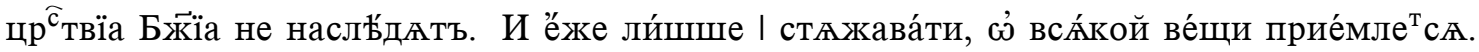
8 ста ${ }^{\widehat{B}} \Gamma^{\widehat{\Lambda}}:$ ла.

\section{Conclusions}

The list presented above can hardly be considered exhaustive. The Lexicon also contains quite a few references to the Bible, the Gospels and the Apostle. Some of the material mentioned in the previous pages was taken by Berynda from the Lexis by Lavrenty Zizany, as well as from the Onomasticon annexed to the Antwerp Bible. Compiling a complete index of sources is the task of the future editors of the Lexicon; at the same time, we hope that the information contained in this study will contribute to the identification of the complete list of all quotes from the Lexicon by the scholars studying Pamvo Berynda's works.

As can be observed from the list presented above, first and foremost, for his Lexicon Berynda used the printed editions to which he contributed personally, namely Homilies to the Acts of Apostles and Homilies on the 14 Epistles of Sain Paul the Apostle by John Chrysostom, as well as the Didactic Gospel. At the same time, the author was interested in the lexicographical sources; these include Interpretation of words difficult to understand by Maximus the Greek. The materials of Berynda's Lexicon were also used for the compilation of Sergy Shelonin's Azbukovnik from Solovky. Knowing the sources of Berynda's Lexicon will be useful for lexicographers aiming at the identification of hidden quotes in the later azbukovniks and lexicons.

\section{Bibliography}

Alekseev, M.P. (1968). Словари иностранньх слов в русском азбуковнике ХVII века: Исследование, тексты и комментарии, Наука, Leningrad.

Arkhangel'skiĭ, А.С. (1902). Памва Берьъда, în Русский биографический словарь: Павел, преподобньий - Петр (Илейка), edition supervised by the president of the Imperial Russian History Society, A.A. Polovtsov, vol. 13, I. N. Skorohodov's typography, Sankt-Petersburg, p. 164-168.

Janów, J. (1951). Leksikografia wschodno-stowiańska do końca XVII w. Cz. II, 2. Etymologie Maksyma Greka, ManuelaRetora i innych autorów $w$ stowniku imion P. Beryndy z 1627 r., in "Sprawozdania z czynności i posiedzeń Polskiej Akademii Umiejętnošci”, LII (6), p. 466-474.

Kalugin, V.V. (2014), Сочинения Максима Грека в “Аексиконе славеноросском" Памвы Берьндыь, іп “Россия и Христианский Восток. Nr. IV-V”, Languages of slavonic culture, Moscow, p. 189-201.

Kovtun, L.S. (1963). Русская лексикография эпохи Средневековья, The Publishing House of the USSR Academy of Sciences, Moscow/Leningrad.

Kuzminova, Е.А. (2000). Грамматика Ааврентия Зизания и Мелетия Смотрищкого, edition, comments and notes by , preface by E. A. Kuzminova, M.L. Remniova, Moscow State University Publishing House, Moscow/Leningrad.

Nimciuk, V.V. (1961). Памво Беринда і його “Аексиконб славенорсоскій и именъ тлькованїе”, in Аексикон словеноросьский Памви Беринди, edition and preface by V.V. Nimciuk, The Publishing House of the Ukrainean RSS Academy of Sciences, p. V-XXXVI. 